Article

\title{
Enzymatic Browning in Banana Blossoms and Techniques for Its Reduction
}

\author{
Geerada Kaewjumpol $^{1}\left(\mathbb{D}\right.$, Surasak Srisamlee ${ }^{1}$, Diane M. Beckles ${ }^{2} \mathbb{D}$ and Kietsuda Luengwilai ${ }^{1,3, * \mathbb{D}}$ \\ 1 Department of Horticulture, Faculty of Agriculture at Kamphaeng Saen, Kamphaeng Saen Campus, \\ Kasetsart University, Nakhon Pathom 73140, Thailand; geerada20@gmail.com (G.K.); surasak.sri@ku.th (S.S.) \\ 2 Department of Plant Sciences, Mail Stop 3, University of California, Davis, CA 95616, USA; \\ dmbeckles@ucdavis.edu \\ 3 Postharvest Technology Innovation Center, Ministry of Higher Education, Science, Research and Innovation, \\ Bangkok 10400, Thailand \\ * Correspondence: kietsuda.1@ku.th
}

check for updates

Citation: Kaewjumpol, G.; Srisamlee, S.; Beckles, D.M.; Luengwilai, K. Enzymatic Browning in Banana Blossoms and Techniques for Its Reduction. Horticulturae 2021, 7, 373. https: / / doi.org/10.3390/

horticulturae7100373

Academic Editors: Maria

Dulce Carlos Antunes, Custódia

Maria Luís Gago and

Adriana Guerreiro

Received: 5 September 2021

Accepted: 30 September 2021

Published: 7 October 2021

Publisher's Note: MDPI stays neutral with regard to jurisdictional claims in published maps and institutional affiliations.

Copyright: (c) 2021 by the authors. Licensee MDPI, Basel, Switzerland. This article is an open access article distributed under the terms and conditions of the Creative Commons Attribution (CC BY) license (https:/ / creativecommons.org/licenses/by/ $4.0 /)$.

\begin{abstract}
Banana blossoms are rich in fiber and nutrients and are a popular plant-based, vegan alternative to fish. However undesirable browning, usually visible at the peduncle cut-end, negatively impacts consumer acceptability of banana blossoms. The aim of this work was to develop safe alternatives to prevent browning in banana blossoms. First, the activities of primary enzymes associated with tissue browning, i.e., polyphenol oxidase (PPO), peroxidase (POD) and phenylalanine ammonia lyase (PAL), were assayed. Our data showed that PPO and POD were the key enzymes responsible for blossom browning as they increased in activity, reaching a maximum at $\mathrm{pH} 7$, as browning developed. In contrast, PAL activity decreased, and total phenolic content did not change as browning progressed, indicating PAL was not induced by cutting and may not be involved in blossom browning. Second, to find antibrowning agents for banana blossoms that can substitute for the use of sodium metabisulfite (SMS), different organic acids of varying concentrations were tested. Among organic acids studied, treatment with $3 \%(w / v)$ oxalic acid was the most effective method and thus could be a safe substitution for SMS to prevent browning in banana blossoms.
\end{abstract}

Keywords: banana buds; antibrowning techniques; PPO; POD; PAL

\section{Introduction}

Banana blossoms (widely known as flower buds) are purple-skinned bracts that develop at the end of the banana fruit cluster. In Southeast Asia, especially Sri Lanka, Malaysia, Indonesia and the Philippines, banana blossoms are a popular ingredient for cooking, and these tissues are rich in many beneficial nutrients, including fiber; protein; vitamins A, C and E; phosphorus; calcium; iron; magnesium; and antioxidants [1,2]. Banana blossoms are also used as a therapeutic agent to lower the risk of anemia [3], increase milk production of breastfeeding mothers [4] and ameliorate the effects of diabetes [5]. However, there is new interest in banana blossoms because they have a texture similar to cooked fish, and they are set to become widely used in vegan cooking [6]. The current price-point for banana blossoms is 14.00 USD per kilogram as a vegan food [6].

After cutting, an undesirable brown color develops at the cut-end surface of banana blossoms. This reduces the nutritional value of the product and is unacceptable to consumers [7-9]. Three key enzymes, polyphenol oxidase (PPO), peroxidase (POD) and phenylalanine ammonia lyase (PAL), are involved in the browning mechanism in plant tissues [10-13]. PPO (EC 1.10.3.1) is widely distributed in the cytoplasm, while its phenolic substrates are in the vacuoles [10]. When cellular organelles are damaged, e.g., when tissues are cut, PPO mixes with phenolic compounds, catalyzing the oxidation of monophenols into $o$-diphenols. A polymerization reaction then converts $o$-diphenols to quinones, which are the precursors to the visible brown pigment seen at the cut surface of 
tissues [10]. POD (EC 1.11.1.7) is a heme-containing enzyme that catalyzes single-electron oxidation of phenolic compounds in the presence of hydrogen peroxide [10]. PAL (EC 4.3.1.5) is the key enzyme in the phenylpropanoid metabolism; it is activated by wounding which leads to the accumulation of phenolic compounds [10]. The relative contribution of these browning enzymes varies according to the species. For example, PAL is the major enzyme responsible for browning in cut lettuce [14], PPO and POD are both important in strawberry [15], and all three enzymes are responsible for browning in peach [16]. In banana, PPO was characterized [17]. However, the relative contribution of PPO, POD and PAL to the browning mechanism in banana blossoms is not known.

Vital factors that limit the rate of the browning reaction include the concentration of related enzymes and phenolic compounds, $\mathrm{pH}$, temperature, and the availability of oxygen to the tissues. Tamarind juice and sodium metabisulfite (SMS) are commonly employed as antibrowning agents to suppress undesirable browning in fresh-cut banana blossoms [18]. However, tamarind juice availability is seasonal and hence unreliable [19] and is thus unsuitable for large-scale production. SMS, while effective, has been restricted for use on most fresh fruit and vegetables in many countries [20]. Therefore, alternative compounds efficient in preventing browning in banana blossoms are required.

Organic acids are considered safe and are widely used as postharvest antibrowning agents. Oxalic acid at $5 \%(w / v)$ reduced browning in longan fruit stored at $25{ }^{\circ} \mathrm{C}$ [21]. Citric acid at $3 \%(w / v)$ suppressed PPO, POD and PAL activities and delayed browning in longkong fruit [22]. Tartaric, citric and ascorbic acids at 3\% $(w / v)$ inhibited POD activity and reduced browning in minimally processed yacon tubers after dipping [23]. Malic acid at $1 \%(v / v)$ suppressed PPO and POD activities and reduced browning of banana skin [24]. Although it has been demonstrated that organic acid treatment significantly reduces browning in a variety of tissues, there are no reports about the use of organic acid treatment to minimize browning in banana blossoms. Here, mechanisms associated with enzymatic browning and the effects of organic acids as antibrowning agents of banana blossoms after cutting were investigated.

\section{Materials and Methods}

\subsection{Chemicals}

L-Ascorbic acid and sodium metabisulfite (SMS) were purchased from Ajax Finechem Pty Ltd. (Taren Point, NSW, Australia). Citric acid monohydrate, sodium dihydrogen phosphate monohydrate and disodium hydrogen phosphate dihydrate were purchased from Merck (Darmstadt, Germany). Oxalic acid, boric acid, sodium carbonate and sodium tetraborate were purchased from KemAus (Cherrybrook, NSW, Australia). Malic acid, tartaric acid, guaiacol, L-phenylalanine catechol, polyvinylpyrrolidone (PVP), gallic acid and 6-hydroxy-2,5,7,8-tetramethylchroman-2-carboxylic acid (Trolox) were purchased from Sigma-Aldrich (Shanghai, China). Bovine serum albumin (BSA) was purchased from Sigma-Aldrich (St. Louis, MO, USA), Folin-Ciocalteu phenol reagent was purchased from Merck (Darmstadt, Germany) and 2,2-diphenyl-1-picrylhydrazyl (DPPH) was purchased from Sigma-Aldrich (Steinheim, Germany). All chemicals were of analytical grade.

\subsection{Banana Blossom Sampling and Postharvest Treatments}

Banana blossoms (Musa ABB 'Kluai Namwa') were collected from the agricultural fields in Kamphaeng Saen district, Nakhon Pathom Province, Thailand. Blossoms were harvested using a fruit picker tool, transported to the laboratory within $5 \mathrm{~h}$ and sorted for uniform size (weight $\sim 500 \mathrm{~g}$ ). The purple-skinned bracts were removed, and only the white-skinned bracts remained. The peduncle of each banana blossom was recut and air-dried before being stored in polyethylene (PE) bags under partial vacuum. To determine the enzymatic browning that occurs in association with wounding and to exclude browning associated with chilling injury, banana blossoms were kept at ambient temperature and humidity $\left(30 \pm 5{ }^{\circ} \mathrm{C}, 72 \pm 7 \% \mathrm{RH}\right)$ for 0,12 and $24 \mathrm{~h}$ to observe browning at the cut-end surface. All experiments were carried out with six replicates, and the whole 
experiments were repeated three times. Similar results were observed; thus, the data from one experiment are presented.

\subsection{Browning Score}

Browning score evaluation was adapted from Lichanporn et al. [25] with some modification. Degree of browning was expressed as the average of six replicates, scored as a visual determination of the peduncle cut-end surface color, where $0=$ completely white (no browning), $1=$ light brown, $3=$ brown and $5=$ dark brown or black.

\subsection{Color Assessment}

Colors on cut-end surfaces were assessed using a Chroma Meter (CR-400, Konica Minolta, Tokyo, Japan) calibrated with a white porcelain reference plate. Color parameters were quantified using the CIE system where $L^{*}$ corresponds to lightness, $a^{*}$ corresponds to redness $\left(+a^{*}\right)$ or green $\left(-a^{*}\right)$ and $b^{*}$ corresponds to yellowness $\left(+b^{*}\right)$ or blue $\left(-b^{*}\right)$. A lower value of $L^{*}$ indicates darker brown color, while a higher value of $+a^{*}$ refers to increased red color [26]. Total color change $\left(\Delta \mathrm{E}^{*}\right)$ was computed by the formula $\Delta \mathrm{E}^{*}=\sqrt{\Delta \mathrm{L}^{* 2}+\Delta \mathrm{a}^{* 2}+\Delta \mathrm{b}^{* 2}}$, where $\Delta \mathrm{L}^{*}, \Delta \mathrm{a}^{*}$ and $\Delta \mathrm{b}^{*}$ represent differences in lightness, redness and yellowness, respectively, before and after the specified period of storage duration [27]. Differences in perceivable color were analytically classified as very distinct $(\Delta \mathrm{E}>3)$, distinct $(1.5<\Delta \mathrm{E}<3)$ and small difference $(1.5<\Delta \mathrm{E})[28]$.

\subsection{Total Phenolic Compounds}

Crude extracts were extracted from the peduncle cut-end of banana blossom and analyzed for phenolic content and DPPH scavenging activity. Banana blossom peduncles $(24 \mathrm{~g})$ were homogenized in $100 \mathrm{~mL}$ of $80 \%$ methanol $(v / v)$ and centrifuged at $19,230 \times g$ at $4{ }^{\circ} \mathrm{C}$ for $10 \mathrm{~min}$. The supernatant was collected and total phenolic content (TPC) was determined by the Folin-Ciocalteu method [29]. A mixture of $0.3 \mathrm{~mL}$ of crude extract and $2.25 \mathrm{~mL}$ of Folin-Ciocalteu phenol reagent (Folin:DI water; 1:10 v/v) was left for $5 \mathrm{~min}$ at $25 \pm 3{ }^{\circ} \mathrm{C}$. Then, $2.25 \mathrm{~mL}$ of $7 \%$ sodium carbonate was added to the mixture, which was vortexed and left in the dark at $25 \pm 3{ }^{\circ} \mathrm{C}$ for $90 \mathrm{~min}$. The reaction was then measured at $725 \mathrm{~nm}$ by a spectrophotometer. The standard curve was established by gallic acid equivalent (GAE) and expressed as $\mu \mathrm{g}$ GAE/g FW.

\subsection{DPPH Radical Scavenging Assay}

Radical scavenging activity of the banana blossom peduncle was determined by DPPH assay following the method of Havananda and Luengwilai [29]. A $0.1 \mathrm{~mL}$ aliquot of crude extract was mixed with $1.9 \mathrm{~mL}$ of $0.004 \%$ DPPH solution in methanol, and the mixture was incubated at $25 \pm 3{ }^{\circ} \mathrm{C}$ under dark condition for $30 \mathrm{~min}$. Absorbance was read at $515 \mathrm{~nm}$. Percentage DPPH inhibition was calculated by Equation (1) [30].

$$
\text { DPPH inhibition }(\%)=\mathrm{A}_{0}-\mathrm{A}_{1} / \mathrm{A}_{0} \times 100
$$

where $A_{0}$ is absorbance of the control (using methanol instead of crude extracts) and $A_{1}$ is absorbance of the reaction mixture.

\subsection{Phenylalanine Ammonia Lyase (PAL) Activity Assay}

PAL was extracted from the peduncle of banana blossom. One gram of the cut-end peduncle surface was extracted with $10 \mathrm{~mL}$ of $0.1 \mathrm{M}$ borate-boric acid buffer ( $\mathrm{pH} 8.8$ ) solution containing $0.2 \mathrm{~g}$ of insoluble PVP and then homogenized for $1 \mathrm{~min}$ on ice using a Polytron PT2100 (Kinematica, Luzern, Switzerland). The homogenate was filtered through layers of cheesecloth before centrifugation at $12,000 \times \mathrm{g}$ for $30 \mathrm{~min}$ at $4{ }^{\circ} \mathrm{C}$ (Model 6500, Kubota Corporation, Tokyo, Japan). The supernatant was collected for PAL activity assay, measured according to Faragher and Chalmers [31] with some modifications.

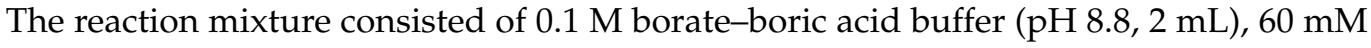


L-phenylalanine $(0.7 \mathrm{~mL})$ and PAL extract $(0.3 \mathrm{~mL})$. The mixture was incubated for $1 \mathrm{~h}$ at $30^{\circ} \mathrm{C}$, then the reaction was stopped with $5 \mathrm{~N} \mathrm{HCl}(0.5 \mathrm{~mL})$. During incubation, the reaction of transforming L-phenylalanine into trans-cinnamic acid was catalyzed by PAL activity and assayed by measuring the increase in trans-cinnamic acid at $280 \mathrm{~nm}$ using a UV-vis spectrophotometer (Thermo Spectronic, Rochester, NY, USA). The standard curve was created by L-phenylalanine, related to a rise in the amount of trans-cinnamic acid, with PAL activity recorded as mmol trans-cinnamic acid $/ \mathrm{h} / \mathrm{mg}$ protein.

\subsection{Polyphenol Oxidase (PPO) and Peroxidase (POD) Activity Assays and Their Optimal pH Condition for Their Activities}

A $2.5 \mathrm{~g}$ cut-end surface of banana peduncle was homogenized for $1 \mathrm{~min}$ at $4{ }^{\circ} \mathrm{C}$ in $0.1 \mathrm{M}$ sodium phosphate buffer $(\mathrm{pH} 7.0,5 \mathrm{~mL})$ containing $0.2 \mathrm{~g}$ of an insoluble PVP. The homogenate was filtered through layers of cheesecloth before centrifugation at $12,000 \times g$ for $10 \mathrm{~min}$ at $4{ }^{\circ} \mathrm{C}$. The supernatant was collected for PPO and POD assays following [32,33]. The reaction mixture of PPO activity consisted of $0.1 \mathrm{M}$ sodium phosphate buffer ( $\mathrm{pH}$ 7.0, $0.4 \mathrm{~mL}), 0.1 \mathrm{M}$ catechol $(0.5 \mathrm{~mL})$ and PPO extract $(0.1 \mathrm{~mL})$. Absorbance was measured at $420 \mathrm{~nm}$. The reaction mixture of POD activity contained $0.1 \mathrm{M}$ sodium phosphate buffer (pH 7.0, $0.8 \mathrm{~mL}), 8 \mathrm{mM}$ guaiacol $(0.05 \mathrm{~mL})$, POD extract $(0.1 \mathrm{~mL})$ and $24 \mathrm{mM}$ hydrogen peroxide $\left(\mathrm{H}_{2} \mathrm{O}_{2}, 0.05 \mathrm{~mL}\right)$. Absorbance was measured at $470 \mathrm{~nm}$. PPO and POD specific enzyme activities were defined as increase in absorbance per min in $1 \mathrm{mg}$ protein in enzyme of the reaction mixture (A $420 / \mathrm{min} / \mathrm{mg}$ protein for $\mathrm{PPO}$ activity and $\mathrm{A} 470 / \mathrm{min} / \mathrm{mg}$ protein for POD activity). Protein contents in PAL, PPO and POD extract solutions were analyzed using bovine serum albumin (BSA) as a standard [34].

To determine their optimal $\mathrm{pH}$ conditions for enzyme activities, PPO and POD activities were monitored at different $\mathrm{pH}$ values ranging from 1 to 7 . All procedures followed those described above, except that the reaction buffer, i.e., $0.1 \mathrm{M}$ sodium phosphate buffer ( $\mathrm{pH} 7.0$ ) was replaced by $0.1 \mathrm{M}$ citric acid-0.15 M HCl ( $\mathrm{pH} 1$ and 2) or $0.3 \mathrm{M}$ citratephosphate buffer (pH 3 to 7 ).

\subsection{Inhibition of $P P O$ and POD Activities Using Different Organic Acids as Inhibitors}

The inhibitory effects of different organic acids on PPO and POD activities were tested. Tartaric (TA), citric (CA), malic (MA), oxalic (OA) and ascorbic (AA) acids at 1, 3 and $5 \%(w / v)$ dissolved in $0.1 \mathrm{M}$ phosphate buffer $(\mathrm{pH} 7.0)$ were used. Crude enzymes were extracted following the same procedure described in Section 2.7. The PPO activity assay consisted of $0.1 \mathrm{~mL}$ crude enzyme extract, $0.1 \mathrm{~mL}$ of $0.1 \mathrm{M}$ sodium phosphate buffer (pH 7.0), $0.5 \mathrm{~mL}$ of $0.1 \mathrm{M}$ catechol and $0.3 \mathrm{~mL}$ of inhibitor (organic acid), while the POD activity assay employed $0.5 \mathrm{~mL}$ of $0.1 \mathrm{M}$ sodium phosphate buffer ( $\mathrm{pH} 7.0), 0.05 \mathrm{~mL}$ of $8 \mathrm{mM}$ guaiacol, $0.3 \mathrm{~mL}$ of inhibitor, $0.05 \mathrm{~mL}$ of $24 \mathrm{mM} \mathrm{H}_{2} \mathrm{O}_{2}$ and $0.1 \mathrm{~mL}$ of crude enzyme extract. The positive control was the reaction mixture without inhibitor, while the negative control was the reaction mixture without crude extract. Percentage inhibitions of PPO and POD activities were calculated using Equation (2) [35].

$$
\text { Inhibition of enzyme activity }(\%)=\mathrm{A}_{\mathrm{c}}-\mathrm{A}_{\mathrm{i}} / \mathrm{A}_{\mathrm{c}} \times 100
$$

where $A_{c}$ is initial PPO or POD activity (without inhibitor) and $A_{i}$ is PPO or POD activity with inhibitor.

\subsection{Antibrowning of Banana Blossoms by Different Organic Acids}

The blossoms were harvested and prepared as described in Section 2.2. The peduncle of banana blossom was recut and dipped for $5 \mathrm{~min}$ in $5 \%(w / v)$ TA, $3 \%(w / v)$ OA or $3 \%$ $(w / v)$ AA (the optimal concentrations were selected based on preliminary experiments). DI water was used as the negative control, and 1\% $(w / v)$ SMS and 2.5\% $(w / v)$ tamarind juice (TJ) were used as positive controls. Samples were dried with a paper towel before being packed into PE bags under partial vacuum and stored at $15 \pm 2{ }^{\circ} \mathrm{C}$ and $90 \pm 5 \% \mathrm{RH}$ in the dark for 0,5 and 10 days. These storage conditions, i.e., temperature, humidity, and 
duration, were found to be optimal for banana blossom shelf-life based on preliminary testing. Cut-end surfaces of the peduncle were monitored for weight loss and color changes before ( 0 days) and after storage ( 5 and 10 days). All experiments were carried out in five replicates and the entire experiment was repeated three times. Similar results were observed; thus, the data from one experiment are presented.

\subsection{Determination of Weight Loss Rate}

The difference between tissue mass before and after storage, in relation to mass before storage, was calculated and expressed as a percentage of the initial fresh weight.

\subsection{Statistical Analysis}

All experiments were conducted using a completely randomized design (CRD) with six replicates, unless otherwise stated. Results were analyzed using the SPSS software program version 19 for Windows (SPSS Inc., IBM Company, Chicago, IL, USA). SPSS was used for analysis of variance (ANOVA) and to estimate significant differences between the means, using Tukey's multiple range test. Acceptable significant difference was set at $p<0.05$. Correlations between enzyme activities, color parameters, phenolic contents and DPPH scavenging activities were also tested by Pearson's correlation coefficient using SPSS software. The principal component analysis (PCA) was analyzed using PAST4.0 software [36].

\section{Results}

\subsection{Browning of Banana Blossom Cut-End Surfaces}

Browning scores increased sharply from 1.2, when assayed at harvest, to 4.2, after $12 \mathrm{~h}$ storage at $30{ }^{\circ} \mathrm{C}$. Color components $\left(\mathrm{L}^{*}, \mathrm{a}^{*}\right.$ and $\left.\mathrm{b}^{*}\right)$ measured by a colorimeter at the cut-end surfaces of the banana blossoms were also determined. At $12 \mathrm{~h}$ after harvest, the $L^{*}$ value significantly decreased from 77.5 to 55.7 , while the $a^{*}$ value increased from -2.7 to 4.2 giving a total color change of $\Delta \mathrm{E}^{*} \sim 21$. In contrast, $\mathrm{b}^{*}$ value was not significantly changed during $24 \mathrm{~h}$. In addition, browning and color components of the cut-end surface after $24 \mathrm{~h}$ were not significantly different from those at $12 \mathrm{~h}$ (Table 1 ).

\subsection{Total Phenolic Content (TPC) and DPPH}

At harvest, banana blossoms had a TPC of $46.5 \mu \mathrm{g} \mathrm{GAE} / \mathrm{g} \mathrm{FW}$, and this amount did not change after $24 \mathrm{~h}$ (Figure 1A). The antioxidant activity of the banana blossoms was evaluated using the DPPH scavenging assay. Similar to TPC, antioxidant activity was not statistically different at $24 \mathrm{~h}$ after harvest. DPPH values ranged from 48.3 to $60.9 \%$ inhibition (Figure 1A).

\subsection{PAL, PPO and POD Activities}

The activities of PAL, PPO and POD in the banana blossoms were low after cutting. POD and PPO activities linearly increased from 1.25 to 6.14 and 0.5 to $1.8 \mathrm{unit} / \mathrm{min} / \mathrm{mg}$ protein, respectively, $12 \mathrm{~h}$ after cutting, remaining high after storage for $24 \mathrm{~h}$. In contrast, PAL activity linearly decreased after storage for $24 \mathrm{~h}$ from 1.7 to $1.2 \mathrm{mmol}$ trans-cinnamic $\mathrm{acid} / \mathrm{h} / \mathrm{mg}$ protein (Figure 1B).

\subsection{TPC, DPPH, PPO, POD and PAL Activities Related to Browning of Banana Blossoms after Cutting}

Negative correlations were shown between $\mathrm{L}^{*}$ (indicative of lightness) and PPO activity $(r=-0.957)$ and between $\mathrm{L}^{*}$ and POD activity $(r=-0.752)$, while positive correlations were found between browning score and PPO activity $(r=0.954)$ and between browning score and POD activity $(r=0.782)$. In contrast, $L^{*}$ was positively correlated with PAL activity $(r=0.828)$, which was negatively correlated with browning score $(r=-0.840)$. Phenolic content and DPPH scavenging activity were stable throughout the $24 \mathrm{~h}$ period 
after cutting, with a weak relationship found between $\mathrm{L}^{*}$ and the browning score, phenolic content and DPPH scavenging activity $(r<0.54)$ (Table 2).

Table 1. Browning of banana blossom cut-end surfaces after cutting. Lightness $\left(\mathrm{L}^{*}\right)$, redness $\left(\mathrm{a}^{*}\right)$, yellowness $\left(\mathrm{b}^{*}\right)$, total color change $\left(\Delta \mathrm{E}^{*}\right)$ and browning score of the cut-end peduncle surface of banana blossoms stored at $30{ }^{\circ} \mathrm{C}$ for 0,12 and $24 \mathrm{~h}$.

\begin{tabular}{|c|c|c|c|c|c|}
\hline Storage Time (h) & $\mathbf{L}^{*}$ & $a^{*}$ & $\mathbf{b}^{*}$ & $\Delta \mathrm{E}^{*}$ & Browning Score \\
\hline 0 & $75.5 \pm 0.6 \mathrm{a}$ & $-2.7 \pm 0.2 \mathrm{~b}$ & $20.9 \pm 1.7 \mathrm{NS}$ & - & $1.2 \pm 0.4 \mathrm{~b}$ \\
\hline 12 & $55.7 \pm 8.6 b$ & $4.2 \pm 3.2 \mathrm{a}$ & $22.9 \pm 1.8 \mathrm{NS}$ & $21.2 \pm 2.8 \mathrm{NS}$ & $4.2 \pm 0.8 \mathrm{a}$ \\
\hline 24 & $55.9 \pm 10.1 \mathrm{~b}$ & $4.8 \pm 3.5 \mathrm{a}$ & $23.1 \pm 1.1 \mathrm{NS}$ & $21.6 \pm 3.2 \mathrm{NS}$ & $4.3 \pm 0.6 \mathrm{a}$ \\
\hline
\end{tabular}

Data are means $\pm \operatorname{SD}(n=6)$. Means followed by different letters in the same columns indicate significant differences $(p<0.05)$ between storage times. NS indicates nonsignificant differences $(p \geq 0.05)$ between storage times.

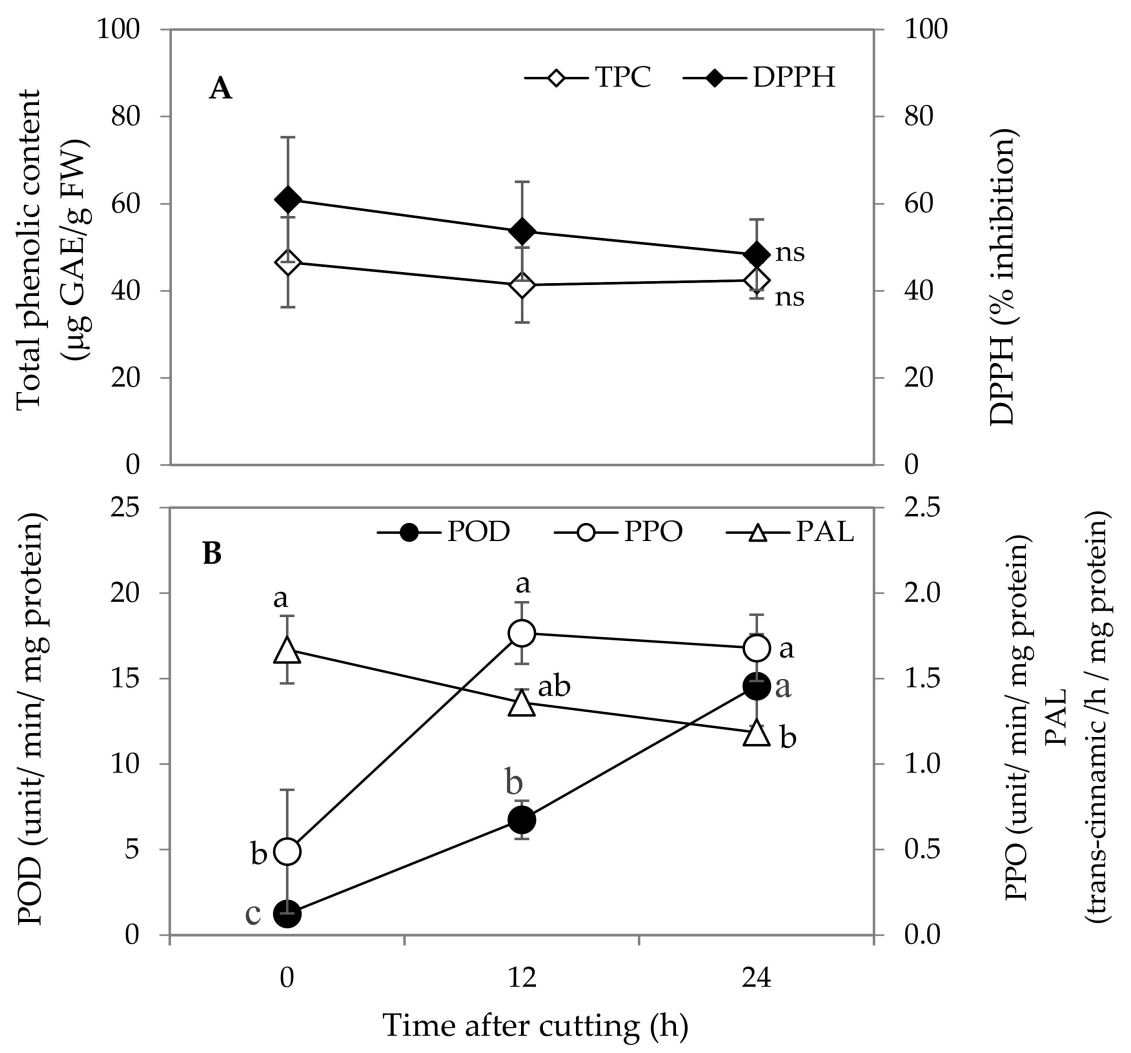

Figure 1. Substrates and enzyme activities associated with browning in cut banana blossom peduncles. Total phenolic content (TPC) and DPPH scavenging activity (A); activities of polyphenol oxidase (PPO), peroxidase (POD) and phenylalanine ammonia lyase (PAL) (B). Activity and content were assayed in banana blossoms stored at $30^{\circ} \mathrm{C}$ for 0,12 and $24 \mathrm{~h}$. Data are shown as mean \pm SD. Different letters $(\mathrm{a}-\mathrm{c})$ on the line graph of PPO, POD and PAL activities indicate significant differences $(p<0.05)$ between storage times. ns on the line graph of TPC and DPPH indicates nonsignificant differences $(p \geq 0.05)$ between storage times. 
Table 2. Substrates and enzyme activities in relation to browning of banana blossoms after cutting. Pearson's correlation coefficients $(r)$ between activities of polyphenol oxidase (PPO), peroxidase (POD) and phenylalanine ammonia lyase (PAL); browning scores; color parameters; phenolic content; and DPPH scavenging activity.

\begin{tabular}{lccccccc}
\hline & PAL & PPO & POD & L Value $^{*}$ Browning Score & Phenolic Content & DPPH Assay \\
\hline PAL & 1.000 & & & & & & \\
PPO & $-0.829^{* *}$ & 1.000 & & & & \\
POD & $-0.870^{* *}$ & 0.660 & 1.000 & & & \\
$L^{*}$ value & $0.826^{* *}$ & $-0.957^{* *}$ & $-0.752^{*}$ & 1.000 & & 1.000 & \\
Browning score & $-0.840^{* *}$ & $0.954^{* *}$ & $0.782^{*}$ & -0.977 & -0.402 & $0.923^{* *}$ \\
Phenolic content & 0.430 & -0.547 & -0.187 & 0.317 & -0.532 & 1.000 \\
DPPH assay & 0.638 & -0.590 & -0.481 & 0.423 & & \\
\hline
\end{tabular}

${ }^{*}$ indicates a significant correlation at $p<0.05 .{ }^{* *}$ indicates a significant correlation at $p<0.01$.

\subsection{Optimal $p H$ for $P P O$ and POD Activities}

One important aim of this study, apart from identifying antibrowning agents, was to identify the $\mathrm{pH}$ optima of PPO and POD. The $\mathrm{pH}$ within plant cells and of all organic acids is naturally below 7 . Therefore, $\mathrm{pHs}$ above $\mathrm{pH} 7$ were not included in this study because they would not be physiologically relevant. By monitoring the PPO and POD activities at $\mathrm{pH}$ between 1 and 7, it was found that the optimal $\mathrm{pH}$ for PPO was 7, whereas a broad optimal $\mathrm{pH}$ range of 4-7 was found for POD. Rapid loss of PPO activity occurred below $\mathrm{pH}$ 7. PPO activity was relatively stable between $\mathrm{pH} 6$ and $\mathrm{pH} 4$ before decreasing to minimal activity below $\mathrm{pH} 3$. For POD, the activity remained steady at $\mathrm{pH} 7-4$ and then decreased to minimal activity below $\mathrm{pH} 2$ (Figure 2).
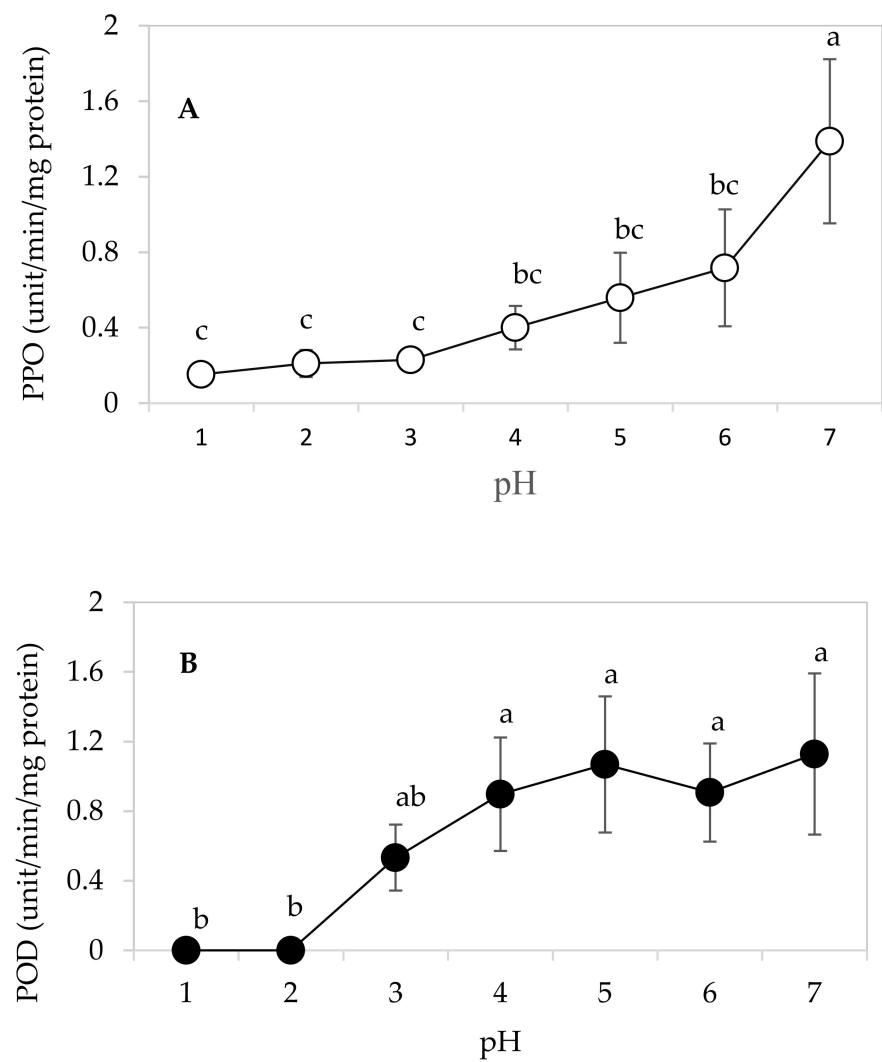

Figure 2. Optimal $\mathrm{pH}$ for polyphenol oxidase (PPO) and peroxidase (POD) activities. Activities of PPO (A) and POD (B) at different $\mathrm{pH}$ values. Enzymes were assayed at $\mathrm{pH} 1$ and 2 using $0.1 \mathrm{M}$ citric acid-0.15 M HCL and at $\mathrm{pH} 3$ to 7 using $0.3 \mathrm{M}$ using citrate-phosphate buffer. Data are mean \pm SD $(n=3)$. Different letters $(\mathrm{a}-\mathrm{c})$ on the line graph of PPO and POD activities indicate significant differences $(p<0.05)$ between different $\mathrm{pH}$ conditions. 


\subsection{Effects of Organic Acids as Inhibitors on PPO and POD Activities of Banana Blossoms}

Overall, most of the acid treatments reduced PPO activity by $75-90 \%$, except for $1 \%$ citric acid and tartaric acid which led to merely $46 \%$ and $68 \%$ inhibition, respectively (Table 3). POD activity was 100\% inhibited when 5\% tartaric acid, $3-5 \%$ oxalic acid and ascorbic acid were used. Other acids, i.e., 3\% tartaric acid, 5\% malic acid and 5\% citric acid, also effectively inhibited POD activity by $75-83 \%$. Some acids, i.e., citric, malic, oxalic, and ascorbic acids at the lowest concentrations used, i.e., $1 \%$, did not inhibit POD activity. All organic acids at $3-5 \%$ had $\mathrm{pH}$ lower than 4 , except for $1 \%$ ascorbic acid with $\mathrm{pH}$ of 6 . All organic acids, except for $1 \%$ ascorbic acid, inhibited PPO activity. Although control treatment (reaction buffer without organic acid agents) with a $\mathrm{pH}$ lower than 3 could inhibit PPO and POD activity by more than $50 \%, 3 \%$ citric acid and malic acid also had pHs lower than 3 , but could inhibit POD activity to $0 \%$ and $36 \%$, respectively (Table 3 ).

Table 3. Inhibition of PPO and POD activities using different organic acids as inhibitors. Percentage inhibition of PPO and POD activities by five organic acids of varying concentrations and their natural $\mathrm{pH}$.

\begin{tabular}{ccccc}
\hline $\begin{array}{c}\text { Organic Acid } \\
\text { Agents }\end{array}$ & $\begin{array}{c}\text { Organic Acid } \\
\text { Concentration }\end{array}$ & $\mathbf{p H}$ & \multicolumn{2}{c}{ Inhibition of Enzyme Activity (\%) } \\
\cline { 4 - 5 } Control $^{1 /}$ & $0 \%$ & $7.0 \pm 0.0$ & $0 \pm 0 \mathrm{~d}$ & $\mathbf{P O D}$ \\
& & $5.0 \pm 0.0$ & $39 \pm 2 \mathrm{c}$ & $4 \pm 7 \mathrm{~d}$ \\
& & $3.0 \pm 0.0$ & $82 \pm 7 \mathrm{a}$ & $52 \pm 7 \mathrm{bc}$ \\
TA & $1.0 \pm 0.0$ & $88 \pm 3 \mathrm{a}$ & $100 \pm 0 \mathrm{a}$ \\
\hline CA & $1 \%$ & $3.3 \pm 0.4 \mathrm{~b}$ & $68 \pm 8 \mathrm{ab}$ & $25 \pm 18 \mathrm{c}$ \\
& $3 \%$ & $2.5 \pm 0.3 \mathrm{c}$ & $86 \pm 4 \mathrm{a}$ & $77 \pm 9 \mathrm{~b}$ \\
& $5 \%$ & $1.7 \pm 0.6 \mathrm{c}$ & $83 \pm 3 \mathrm{a}$ & $99 \pm 2 \mathrm{a}$ \\
\hline MA & $1 \%$ & $4.0 \pm 0.0 \mathrm{~b}$ & $46 \pm 11 \mathrm{~b}$ & $0 \pm 0 \mathrm{~d}$ \\
& $3 \%$ & $2.8 \pm 0.0 \mathrm{c}$ & $76 \pm 8 \mathrm{a}$ & $0 \pm 0 \mathrm{~d}$ \\
& $5 \%$ & $2.5 \pm 0.0 \mathrm{c}$ & $83 \pm 4 \mathrm{a}$ & $75 \pm 6 \mathrm{~b}$ \\
\hline OA & $1 \%$ & $3.6 \pm 0.0 \mathrm{~b}$ & $79 \pm 11 \mathrm{a}$ & $0 \pm 0 \mathrm{~d}$ \\
& $3 \%$ & $2.8 \pm 0.0 \mathrm{c}$ & $79 \pm 1 \mathrm{a}$ & $36 \pm 7 \mathrm{c}$ \\
& $5 \%$ & $2.5 \pm 0.0 \mathrm{c}$ & $78 \pm 3 \mathrm{a}$ & $83 \pm 2 \mathrm{~b}$ \\
\hline AA & $1 \%$ & $2.6 \pm 0.0 \mathrm{c}$ & $74 \pm 14 \mathrm{a}$ & $0 \pm 0 \mathrm{~d}$ \\
& $3 \%$ & $0.9 \pm 0.3 \mathrm{~d}$ & $78 \pm 10 \mathrm{a}$ & $100 \pm 0 \mathrm{a}$ \\
& $5 \%$ & $0.7 \pm 0.1 \mathrm{~d}$ & $90 \pm 1 \mathrm{a}$ & $100 \pm 0 \mathrm{a}$ \\
\hline & $1 \%$ & $5.6 \pm 0.1 \mathrm{a}$ & $83 \pm 2 \mathrm{a}$ & $0 \pm 0 \mathrm{~d}$ \\
& $3 \%$ & $2.7 \pm 0.9 \mathrm{c}$ & $86 \pm 0 \mathrm{a}$ & $100 \pm 0 \mathrm{a}$ \\
& $5 \%$ & $2.6 \pm 0.8 \mathrm{c}$ & $87 \pm 7 \mathrm{a}$ & $100 \pm 0 \mathrm{a}$ \\
\hline
\end{tabular}

1/ The control was the reaction mixture without organic acids but with the $\mathrm{pH}$ adjusted with $\mathrm{HCl}$. TA $=$ tartaric acid, $\mathrm{CA}=$ citric acid, $\mathrm{MA}=$ malic acid, $\mathrm{OA}=$ oxalic acid and $\mathrm{AA}=$ ascorbic acid. Data are shown as mean $\pm \mathrm{SD}$ $(n=6)$. Means in columns with different letters indicate significant differences $(p<0.05)$ between different inhibitors at different concentrations.

Three synthetic organic acids at the lowest concentrations of tartaric acid (5\%), oxalic acid (3\%) and ascorbic acid (3\%) provided the greatest inhibition of PPO and POD activity. Therefore, $5 \%$ tartaric acid, $3 \%$ oxalic acid and 3\% ascorbic acid were selected for further study.

\subsection{Effect of Antibrowning Agents on Browning and Weight Loss of Banana Blossoms}

Among all compounds tested, $3 \%$ oxalic acid caused the highest inhibition of browning at the blossom cut-surface after storage at $15^{\circ} \mathrm{C}$ for 10 days. The $\mathrm{L}^{*}, \mathrm{a}^{*}$ and $\Delta \mathrm{E}^{*}$ values and browning score of the cut-surface of banana blossom treated with $3 \%$ oxalic acid were better than that of the control (DI water, 2.5\% tamarind juice and 1\% SMS). No significant differences in weight loss among inhibitor agents and storage times were observed (Table 4). There was no abnormal odor and no disease incidence in any of the treated banana blossoms after 10 days of storage (data not shown). 
Table 4. Browning response of banana blossoms after various organic acid treatments. Color, i.e., lightness $\left(\mathrm{L}^{*}\right)$, redness $\left(\mathrm{a}^{*}\right)$ and total color change $\left(\Delta \mathrm{E}^{*}\right)$, was assessed using a colorimeter. Browning score of peduncle cut-end surfaces and weight loss of banana blossoms were calculated as described. All tissues were kept in PE bags at $15^{\circ} \mathrm{C}$ for 0,5 and 10 days.

\begin{tabular}{|c|c|c|c|}
\hline \multirow{2}{*}{ Inhibitor } & \multicolumn{3}{|c|}{$\mathbf{L}^{*}$} \\
\hline & 0 Day & 5 Days & 10 Days \\
\hline DI water & $68.6 \pm 4.6 \mathrm{~B}, \mathrm{a}$ & $60.6 \pm 5.8 \mathrm{~B}, \mathrm{~b}$ & $61.5 \pm 5.5 \mathrm{BC}, \mathrm{b}$ \\
\hline $2.5 \% \mathrm{TJ}$ & $71.4 \pm 3.0 \mathrm{~B}, \mathrm{a}$ & $60.2 \pm 3.3 \mathrm{~B}, \mathrm{~b}$ & $60.1 \pm 2.5 \mathrm{BC}, \mathrm{b}$ \\
\hline $1 \%$ SMS & $75.5 \pm 0.0 \mathrm{~A}, \mathrm{a}$ & $54.3 \pm 6.8 \mathrm{C}, \mathrm{b}$ & $53.4 \pm 6.8 \mathrm{C}, \mathrm{b}$ \\
\hline $5 \%$ TA & $76.9 \pm 0.5 \mathrm{~A}, \mathrm{a}$ & $55.4 \pm 3.2 \mathrm{BC}, \mathrm{b}$ & $55.9 \pm 3.4 \mathrm{BC}, \mathrm{b}$ \\
\hline $3 \% \mathrm{AA}$ & $77.7 \pm 0.7 \mathrm{~A}, \mathrm{a}$ & $59.6 \pm 2.1 \mathrm{~B}, \mathrm{~b}$ & $58.5 \pm 2.5 \mathrm{~B}, \mathrm{~b}$ \\
\hline $3 \% \mathrm{OA}$ & $77.3 \pm 1.4 \mathrm{~A}, \mathrm{a}$ & $66.8 \pm 2.8 \mathrm{~A}, \mathrm{~b}$ & $66.4 \pm 2.4 \mathrm{~A}, \mathrm{~b}$ \\
\hline \multirow{2}{*}{ Inhibitor } & \multicolumn{3}{|c|}{$a^{*}$} \\
\hline & 0 Day & 5 Days & 10 Days \\
\hline DI water & $-0.3 \pm 1.9 \mathrm{AB}, \mathrm{b}$ & $4.9 \pm 2.5 \mathrm{AB}, \mathrm{a}$ & $5.2 \pm 2.4 \mathrm{AB}, \mathrm{a}$ \\
\hline $2.5 \% \mathrm{TJ}$ & $-1.0 \pm 1.7 \mathrm{AB}, \mathrm{b}$ & $5.3 \pm 1.8 \mathrm{AB}, \mathrm{a}$ & $6.3 \pm 1.6 \mathrm{AB}, \mathrm{a}$ \\
\hline $1 \%$ SMS & $0.8 \pm 0.0 \mathrm{~A}, \mathrm{~b}$ & $7.6 \pm 1.4 \mathrm{~A}, \mathrm{a}$ & $4.3 \pm 1.4 \mathrm{~A}, \mathrm{a}$ \\
\hline $5 \%$ TA & $-3.4 \pm 0.3 \mathrm{~B}, \mathrm{~b}$ & $5.2 \pm 1.8 \mathrm{~B}, \mathrm{a}$ & $5.0 \pm 1.8 \mathrm{~B}, \mathrm{a}$ \\
\hline $3 \% \mathrm{AA}$ & $-3.5 \pm 0.3 \mathrm{~B}, \mathrm{~b}$ & $6.3 \pm 1.0 \mathrm{AB}, \mathrm{a}$ & $7.0 \pm 0.5 \mathrm{AB}, \mathrm{a}$ \\
\hline $3 \% \mathrm{OA}$ & $-3.4 \pm 0.6 \mathrm{~B}, \mathrm{~b}$ & $0.0 \pm 0.7 \mathrm{C}, \mathrm{a}$ & $0.0 \pm 0.7 \mathrm{C}, \mathrm{a}$ \\
\hline \multirow{2}{*}{ Inhibitor } & \multicolumn{3}{|c|}{$\Delta \mathrm{E}^{*}$} \\
\hline & 0 Day & 5 Days & 10 Days \\
\hline DI water & & $12.4 \pm 4.3 \mathrm{NS}$ & $11.8 \pm 1.0 \mathrm{NS}$ \\
\hline $2.5 \% \mathrm{TJ}$ & & $13.8 \pm 2.9 \mathrm{NS}$ & $15.5 \pm 3.5 \mathrm{NS}$ \\
\hline $1 \%$ SMS & & $23.4 \pm 2.5 \mathrm{NS}$ & $24.3 \pm 5.5 \mathrm{NS}$ \\
\hline $5 \%$ TA & & $23.4 \pm 2.6 \mathrm{NS}$ & $22.9 \pm 2.8 \mathrm{NS}$ \\
\hline $3 \% \mathrm{AA}$ & & $22.4 \pm 2.0 \mathrm{NS}$ & $23.2 \pm 2.3 \mathrm{NS}$ \\
\hline $3 \% \mathrm{OA}$ & & $11.6 \pm 2.2 \mathrm{NS}$ & $12.0 \pm 1.7 \mathrm{NS}$ \\
\hline \multirow{2}{*}{ Inhibitor } & \multicolumn{3}{|c|}{ Browning score } \\
\hline & 0 Day & 5 Days & 10 Days \\
\hline DI water & $1.0 \pm 0.0 \mathrm{~A}, \mathrm{~b}$ & $3.6 \pm 0.9 \mathrm{~B}, \mathrm{a}$ & $3.6 \pm 0.9 \mathrm{~B}, \mathrm{a}$ \\
\hline $2.5 \% \mathrm{TJ}$ & $1.0 \pm 0.0 \mathrm{~A}, \mathrm{~b}$ & $3.4 \pm 0.5 \mathrm{~B}, \mathrm{a}$ & $3.4 \pm 0.5 \mathrm{~B}, \mathrm{a}$ \\
\hline $1 \%$ SMS & $1.0 \pm 0.5 \mathrm{~A}, \mathrm{~b}$ & $2.8 \pm 0.8 \mathrm{~B}, \mathrm{a}$ & $3.8 \pm 0.8 \mathrm{~B}, \mathrm{a}$ \\
\hline $5 \%$ TA & $1.0 \pm 0.0 \mathrm{~A}, \mathrm{~b}$ & $4.8 \pm 0.4 \mathrm{~A}, \mathrm{a}$ & $5.0 \pm 0.0 \mathrm{~A}, \mathrm{a}$ \\
\hline $3 \% \mathrm{AA}$ & $1.0 \pm 0.0 \mathrm{~A}, \mathrm{~b}$ & $3.8 \pm 0.8 \mathrm{~B}, \mathrm{a}$ & $3.8 \pm 0.8 \mathrm{~B}, \mathrm{a}$ \\
\hline $3 \% \mathrm{OA}$ & $1.0 \pm 0.0 \mathrm{~A}, \mathrm{~b}$ & $2.8 \pm 0.8 \mathrm{~B}, \mathrm{a}$ & $3.8 \pm 1.3 \mathrm{~B}, \mathrm{a}$ \\
\hline \multirow{2}{*}{ Inhibitor } & \multicolumn{3}{|c|}{ Weight loss (\% of initial FW) } \\
\hline & 0 Day & 5 Days & 10 Days \\
\hline DI water & & $0.3 \pm 0.4 \mathrm{AB}, \mathrm{a}$ & $0.8 \pm 0.9 \mathrm{~A}, \mathrm{a}$ \\
\hline $2.5 \% \mathrm{TJ}$ & & $0.5 \pm 0.3 \mathrm{~A}, \mathrm{a}$ & $0.6 \pm 0.3 \mathrm{~A}, \mathrm{a}$ \\
\hline $1 \%$ SMS & & $0.4 \pm 0.2 \mathrm{~A}, \mathrm{a}$ & $0.2 \pm 0.0 \mathrm{AB}, \mathrm{a}$ \\
\hline $5 \%$ TA & & $0.2 \pm 0.1 \mathrm{AB}, \mathrm{a}$ & $0.3 \pm 0.3 \mathrm{AB}, \mathrm{a}$ \\
\hline $3 \% \mathrm{AA}$ & & $0.3 \pm 0.2 \mathrm{AB}, \mathrm{a}$ & $0.5 \pm 0.2 \mathrm{~A}, \mathrm{a}$ \\
\hline $3 \% \mathrm{OA}$ & & $0.2 \pm 0.2 \mathrm{AB}, \mathrm{a}$ & $0.1 \pm 0.1 \mathrm{AB}, \mathrm{a}$ \\
\hline
\end{tabular}

Data are shown as mean \pm SD $(n=5)$. Means in columns with different capital letters indicate significant differences $(p<0.05)$ among inhibitors and means in rows with different small letters indicate significant differences $(p<0.05)$ between storage times. NS indicates nonsignificant differences $(p<0.05)$ among inhibitors and storage times. Inhibitors: $\mathrm{DI}=$ deionized water, $\mathrm{TA}=$ tartaric acid, $\mathrm{OA}=$ oxalic acid, $\mathrm{AA}=$ ascorbic acid, $\mathrm{TJ}=$ tamarind juice and SMS = sodium metabisulfite.

PCA was performed to provide an overview of the differences caused by the four different antibrowning treatments and storage periods on the banana blossoms. The first two principal components together accounted for $73 \%$ of the original variance: PC1 explained $44 \%$, and PC2 explained $29 \%$. Tissues clustered into three distinct groups. In group I, all treated tissues assayed before storage $(0 \mathrm{~d})$ clustered together; the only tissues treated with acid 
and stored that were in this group were those dipped in 3\% oxalic acid. The remaining tissues, all stored for 5 or 10 days, separated into either group II or III. Blossoms treated with DI water, or 2.5\% tamarind juice clustered together, while blossoms treated with $1 \%$ SMS, 3\% ascorbic acid and 5\% tartaric acid formed the remaining cluster (Figure 3). Loading analysis indicated that the $L^{*}$ and $b^{*}$ values with loading scores of -0.83 and 0.91 on PC1 and PC2, respectively, determined the grouping (data not shown).

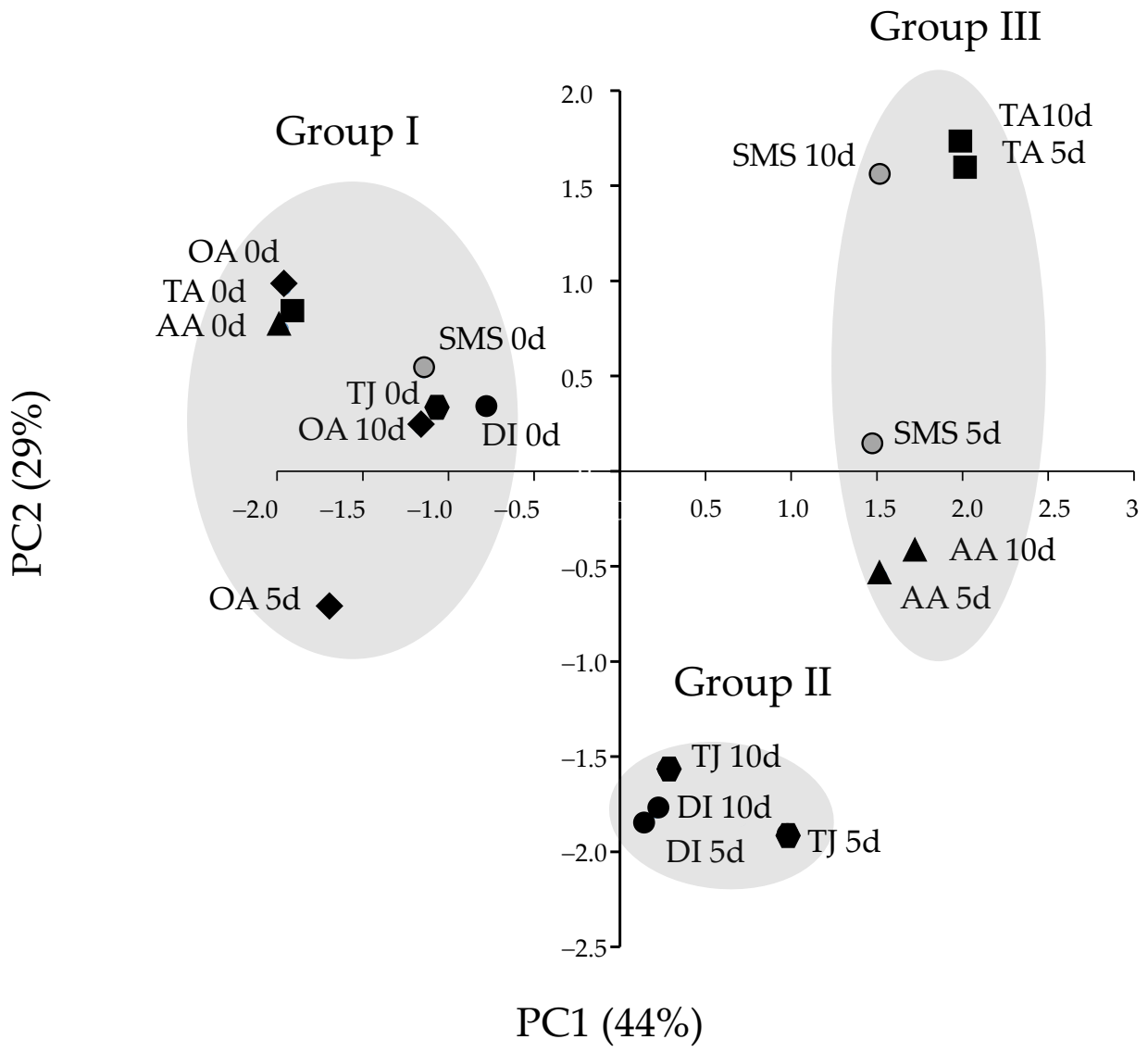

Figure 3. The principal component analysis (PCA) of objective color status and browning of the peduncle cut-end surfaces of banana blossoms after antibrowning treatments. Objective color was assessed by lightness $\left(\mathrm{L}^{*}\right)$, redness $\left(\mathrm{a}^{*}\right)$, yellowness $\left(\mathrm{b}^{*}\right)$ and total color change $\left(\Delta \mathrm{E}^{*}\right)$; the browning score and weight loss of the peduncle cut-end surfaces of banana blossoms were assessed after storage in polyethylene bags at $15^{\circ} \mathrm{C}$ for 0,5 and 10 days. Banana blossoms treated with $3 \%$ oxalic acid (OA) and stored for 5 or 10 days were similar to those on the initial day of treatment. Banana blossoms treated with 3\% ascorbic acid (AA) and 5\% tartaric acid (TA) and stored for 5 or 10 days were similar to those treated with $1 \%$ sodium metabisulfite (SMS) and stored for the equivalent period. Banana blossoms treated with 2.5\% tamarind juice (TJ) and stored for 5 or 10 days were similar to those treated with DI water.

\section{Discussion}

Banana blossoms have been traditionally eaten in dishes in SE Asia for hundreds of years, but there is now a growing demand, both locally and globally, for high-quality blossoms with reduced or no browning. This necessitates an investigation of the postharvest browning of fresh-cut banana blossoms. Here, we examined the activity of key browning enzymes and also investigated acid treatments to prevent undesirable browning.

\subsection{Browning Mechanism at Cut-End Surface of Banana Blossoms}

Browning or blackening from abiotic wounding or cutting occurs by enzymatic oxidation of phenolic compounds [37]. At the site of injury, chemical signals originate 
and propagate into adjacent tissue. This induces the de novo synthesis of phenylalanine ammonia lyase (PAL) activity, the first key enzyme that converts L-phenylalanine to trans-cinnamic acid $[38,39]$ resulting in the accumulation of phenolic compounds. In the presence of oxygen, phenolic compounds are oxidized by PPO to quinones that are highly reactive and can combine with other compounds to form brown pigments [40]. POD, on the other hand, acts as an antioxidant enzyme to eliminate excess hydrogen peroxide $\left(\mathrm{H}_{2} \mathrm{O}_{2}\right)$ [41] and initiates enzymatic browning of fruit and vegetables [42]. Here, PPO and POD activities increased rapidly $12 \mathrm{~h}$ after cutting, in concert with increased browning, while in contrast, PAL activity decreased (Figure 1 and Table 1). Thus, only PPO and POD are induced by wounding, and together they serve as the key enzymes involved in the browning mechanism at the cut-end surface of banana blossoms.

In this study, the phenolic content (TPC) and DPPH scavenging activity of the blossoms were high and did not change as browning progressed (Figure 1). Phenolic compounds contribute to browning by acting as substrates for PPO and POD, and this is true in banana blossoms. The almost constant TPC during browning development indicates that banana blossoms were not limited in the phenolic compounds to supply substrate for PPO and POD.

\subsection{Oxalic Acid Treatment as the Most Effective Method to Prevent Browning after Cutting}

Different organic acids were tested as effective suppressors of the browning that occurs in the peduncle cut-end surface of banana blossoms. Low $\mathrm{pH}$, the presence of a chelating copper ion and the ability to reduce quinones to their original diphenol are the main properties of organic acids that render them capable of inhibiting PPO and POD activities. Since different types and concentrations of organic acids inhibited the browning of banana blossoms differently, diverse inhibitory mechanisms for PPO and POD by each organic acid were assumed. Both browning scores and browning enzyme activities of banana blossoms were most inhibited by $3 \%$ of oxalic acid treatment (Tables 3 and 4). Oxalic acid may have a more effective chelating ability compared to other acids with the same structure $[43,44]$. Oxalic acid can bind to the PPO copper-containing active sites to form an inactive complex, thus reducing browning [45]. This finding agrees with reports on lettuce where oxalic acid diminished catechol quinone formation and no quinone bleaching was observed [46].

The present study also suggested that $\mathrm{pH} 2$ reduced PPO activity and completely inhibited POD activity in the banana blossoms after tissue wounding by cutting. Similar to our results, Oba et al. [17] found that the activity of PPO from 'Saba' banana blossoms was reduced with decreasing $\mathrm{pH}$ from 7.5 to 4 . He and Luo [10] reported that environmental $\mathrm{pH}$ affected the ionizable groups of the PPO and POD protein structures, which in turn would diminish their ability to catalyze their respective browning reactions. An acidic $\mathrm{pH}$ of 3.54 induced the unfolding of the native mushroom PPO with structural changes [47]. Oxalic acid had a low pKa value with a natural $\mathrm{pH}$ of 0.9 when $3 \%$ concentration was used. Thus, the low $\mathrm{pH}$ value of $3 \%$ oxalic acid may partially explain why this treatment was the most effective method to prevent banana blossom browning.

In comparison to the commercial antibrowning agent, i.e., $1 \%$ SMS, treatment with $3 \%$ oxalic acid led to higher browning inhibition at the blossom cut-surface. The $3 \%$ oxalic acid treatment is easy to apply, cost-effective and nontoxic. In this study, the organic acid treatments were applied only at the peduncle cut-end surface of the banana blossoms. Possible negative effects on quality attributes that may be caused by the organic acid treatments include unpleasant coloration, browning, weight loss, abnormal odor or disease incidence. However abnormal odor and disease incidence were not detected after organic acid treatment used in this experiment. Hence, this treatment holds great promise for use as a commercial agent for reduced browning of banana blossoms.

\section{Conclusions}

PPO and POD were identified as the key enzymes involved in browning at the cut-end surface of banana blossoms. Optimal $\mathrm{pH}$ values for PPO and POD activity in banana 
blossoms were $\mathrm{pH} 4-6$ and $\mathrm{pH} 7$, respectively. A pH value of 2 inhibited $\mathrm{PPO}$ and POD activity by as much as $80 \%$ and $100 \%$, respectively. Treatment with $3 \%$ oxalic acid effectively inhibited browning at the cut-end surface of the banana blossom peduncle for 10 days after $15{ }^{\circ} \mathrm{C}$ storage under PE package. It is proposed that $3 \%$ oxalic acid should be widely investigated as an effective commercial treatment to reduce browning and enhance the postharvest quality of banana blossoms.

Author Contributions: G.K. and K.L. planned and designed the experiments; G.K. and S.S. performed the experiments; G.K. and K.L. analyzed the data; G.K., K.L. and D.M.B. wrote the manuscript. All authors have read and agreed to the published version of the manuscript.

Funding: This research was funded by the Postdoctoral Fellowship at Kasetsart University and the Postharvest Technology Innovation Center, Ministry of Higher Education, Science, Research and Innovation, Bangkok, Thailand.

Conflicts of Interest: The authors confirm that they have no conflicts of interest with respect to the work described in this manuscript.

\section{References}

1. Sheng, Z.W.; Ma, W.H.; Jin, Z.Q.; Bi, Y.; Sun, Z.G.; Dou, H.T.; Gao, J.H.; Li, J.Y.; Han, L.N. Investigation of dietary fiber, protein, vitamin $\mathrm{E}$ and other nutritional compounds of banana flower of two cultivars grown in China. Afr. J. Biotechnol. 2010, 9, 3888-3895. [CrossRef]

2. Krishnan, A.; Sinija, V.R. Proximate Composition and Antioxidant Activity of Banana Blossom of Two Cultivars in India. Int. J. Agric. Food Sci. Technol. 2016, 7, 13-22.

3. Anand, S.; Sharma, M. Product Development from Banana Blossom Powder and Indian Gooseberry Powder for Anaemic Adolescent Girls. Int. J. Health Sci. Res. 2019, 9, 273-278.

4. Wahyuningsih, D.; Hidayat, S.T.; Khafidhoh, N.; Suwondo, A.; Fatmasari, D.; Susiloretni, K.A. Effect of Musa Balbisiana Colla Extract on Breast Milk Production in Breastfeeding Mothers. Belitung Nurs. J. 2017, 3, 174-182. [CrossRef]

5. Liyanage, R.; Gunasegaram, S.; Visvanathan, R.; Jayathilake, C.; Weththasinghe, P.; Jayawardana, B.C.; Vidanarachchi, J.K. Banana Blossom (Musa acuminate Colla) Incorporated Experimental Diets Modulate Serum Cholesterol and Serum Glucose Level in Wistar Rats Fed with Cholesterol. Cholesterol 2016, 2016, 9747412. [CrossRef] [PubMed]

6. Berrill, A. Banana blossom: The next vegan food star with the texture of fish. The Guardian, 16 March 2019.

7. Jiang, Y.; Duan, X.; Joyce, D.; Zhang, Z.; Li, J. Advances in understanding of enzymatic browning in harvested litchi fruit. Food Chem. 2004, 88, 443-446. [CrossRef]

8. Vámos-Vigyázó, L.; Haard, N.F. Polyphenol oxidases and peroxidases in fruits and vegetables. Crit. Rev. Food Sci. Nutr. 1981, 15, 49-127. [CrossRef] [PubMed]

9. Moon, K.M.; Kwon, E.B.; Lee, B.; Kim, C.Y. Recent Trends in Controlling the Enzymatic Browning of Fruit and Vegetable Products. Molecules 2020, 25, 2754. [CrossRef] [PubMed]

10. He, Q.; Luo, Y. Enzymatic browning and its control in fresh-cut produce. Stewart Postharvest Rev. 2007, 3, 1-7. [CrossRef]

11. Liu, X.; Wang, T.; Lu, Y.; Yang, Q.; Li, Y.; Deng, X.; Liu, Y.; Du, X.; Qiao, L.; Zheng, J. Effect of high oxygen pretreatment of whole tuber on anti-browning of fresh-cut potato slices during storage. Food Chem. 2019, 301, 125287. [CrossRef] [PubMed]

12. Degl'Innocenti, E.; Pardossi, A.; Tognoni, F.; Guidi, L. Physiological basis of sensitivity to enzymatic browning in "lettuce", "escarole" and "rocket salad" when stored as fresh-cut products. Food Chem. 2007, 104, 209-215. [CrossRef]

13. Li-Qin, Z.; Jie, Z.; Shu-Hua, Z.; Lai-Hui, G. Inhibition of browning on the surface of peach slices by short-term exposure to nitric oxide and ascorbic acid. Food Chem. 2009, 114, 174-179. [CrossRef]

14. Hisaminato, H.; Murata, M.; Homma, S. Relationship between the Enzymatic Browning and Phenylalanine Ammonia-lyase Activity of Cut Lettuce, and the Prevention of Browning by Inhibitors of Polyphenol Biosynthesis. Biosci. Biotechnol. Biochem. 2001, 65, 1016-1021. [CrossRef] [PubMed]

15. Chisari, M.; Barbagallo, R.N.; Spagna, G. Characterization of Polyphenol Oxidase and Peroxidase and Influence on Browning of Cold Stored Strawberry Fruit. J. Agric. Food Chem. 2007, 55, 3469-3476. [CrossRef] [PubMed]

16. Jin, P.; Zheng, Y.; Tang, S.; Rui, H.; Wang, C.Y. A combination of hot air and methyl jasmonate vapor treatment alleviates chilling injury of peach fruit. Postharvest Biol. Technol. 2009, 52, 24-29. [CrossRef]

17. Oba, K.; Uritani, I.; Iwatsuki, N.; Alvarez, A.M.; Garcia, V.V. Partial Purification and Characterization of Polyphenol Oxidase Isozymes in Banana Bud. Biosci. Biotechnol. Biochem. 1992, 56, 1027-1030. [CrossRef] [PubMed]

18. Chomkitichai, W.; Chaiyakhan, Y.; Petphinit, N.; Pudpang, P.; Chomkitichai, W. Effect of Tamarind Juice on Browning Reduction of Fresh-cut Banana Blossom during Storage. Agric. Sci. J. 2018, 4, 91-94. (In Thai)

19. Saideswara Rao, Y.; Mary Mathew, K. Tamarind. In Handbook of Herbs and Spices, 2nd ed.; Peter, K.V., Ed.; Woodhead Publishing Limited: Cambridge, UK, 2012; Volume 2, pp. 512-533. [CrossRef]

20. Tongdee, S. Postharvest Handling and Technology of Tropical Fruit. Acta Hortic. 1992, 713-717. [CrossRef] 
21. Whangchai, K.; Saengnil, K.; Uthaibutra, J. Effect of ozone in combination with some organic acids on the control of postharvest decay and pericarp browning of longan fruit. Crop Prot. 2006, 25, 821-825. [CrossRef]

22. Venkatachalam, K. The Different Concentrations of Citric Acid on Inhibition of Longkong Pericarp Browning during Low Temperature Storage. Int. J. Fruit Sci. 2015, 15, 353-368. [CrossRef]

23. Vasconcelos, C.M.; de Oliveira, E.B.; Rossi, S.N.; Arantes, L.F.; Puschmann, R.; Chaves, J.B.P. Evaluating Strategies to Control Enzymatic Browning of Minimally Processed Yacon (Smallanthus sonchifolius). Food Bioprocess Technol. 2015, 8, 1982-1994. [CrossRef]

24. Huang, H.; Jian, Q.; Jiang, Y.; Duan, X.; Qu, H. Enhanced chilling tolerance of banana fruit treated with malic acid prior to low-temperature storage. Postharvest Biol. Technol. 2016, 111, 209-213. [CrossRef]

25. Lichanporn, I.; Techavuthiporn, C.; Wongs-Aree, C. Effect of Silver Particle-longkong Peel Extract Coating on Postharvest Decay and Browning in Longkong Fruit. Hortic. J. 2020, 89, 328-336. [CrossRef]

26. Moline, H.E.; Buta, J.G.; Newman, I.M. Prevention of browning of banana slices using natural products and their derivatives. J. Food Qual. 1999, 22, 499-511. [CrossRef]

27. Nkhata, S.G. Total color change $(\Delta \mathrm{E} *)$ is a poor estimator of total carotenoids lost during post-harvest storage of biofortified maize grains. Heliyon 2020, 6, e05173. [CrossRef] [PubMed]

28. Adekunte, A.O.; Tiwari, B.K.; Cullen, P.J.; Scannell, A.G.M.; O’Donnell, C.P. Effect of sonication on colour, ascorbic acid and yeast inactivation in tomato juice. Food Chem. 2010, 122, 500-507. [CrossRef]

29. Havananda, T.; Luengwilai, K. Variation in floral antioxidant activities and phytochemical properties among butterfly pea (Clitoria ternatea L.) germplasm. Genet. Resour. Crop. Evol. 2019, 66, 645-658. [CrossRef]

30. Salar, R.K.; Sharma, P.; Purewal, S.S. In Vitro antioxidant and free radical scavenging activities of stem extract of Euphorbia trigona Miller. Tang Humanit. Med. 2015, 5, e14. [CrossRef]

31. Faragher, J.; Chalmers, D. Regulation of Anthocyanin Synthesis in Apple Skin. III. Involvement of Phenylalanine Ammonia-lyase. Funct. Plant Biol. 1977, 4, 133-141. [CrossRef]

32. Benjamin, N.D.; Montgomery, M.W. Polyphenol Oxidase of Royal Ann Cherries: Purification and Characterization. J. Food Sci. 1973, 38, 799-806. [CrossRef]

33. Zhang, Z.; Pang, X.; Xuewu, D.; Ji, Z.; Jiang, Y. Role of peroxidase in anthocyanin degradation in litchi fruit pericarp. Food Chem. 2005, 90, 47-52. [CrossRef]

34. Bradford, M.M. A rapid and sensitive method for the quantitation of microgram quantities of protein utilizing the principle of protein-dye binding. Anal. Biochem. 1976, 72, 248-254. [CrossRef]

35. Zhang, X.; Shao, X. Characterisation of polyphenol oxidase and peroxidase and the role in browning of loquat fruit. Czech J. Food Sci. 2015, 33, 109-117. [CrossRef]

36. Hammer, Ø.; Harper, D.A.T.; Ryan, P.D. PAST: Paleontological statistics software package for education and data analysis. Palaeontol. Electron. 2001, 4, 9.

37. Ahvenainen, R. New approaches in improving the shelf life of minimally processed fruit and vegetables. Trends Food Sci. Technol. 1996, 7, 179-187. [CrossRef]

38. Ngadze, E.; Icishahayo, D.; Coutinho, T.A.; van der Waals, J.E. Role of Polyphenol Oxidase, Peroxidase, Phenylalanine Ammonia Lyase, Chlorogenic Acid, and Total Soluble Phenols in Resistance of Potatoes to Soft Rot. Plant Dis. 2012, 96, 186-192. [CrossRef] [PubMed]

39. Saltveit, M.E. Wound induced changes in phenolic metabolism and tissue browning are altered by heat shock. Postharvest Biol. Technol. 2000, 21, 61-69. [CrossRef]

40. Mayer, A.M. Polyphenol oxidases in plants and fungi: Going places? A review. Phytochemistry 2006, 67, 2318-2331. [CrossRef] [PubMed]

41. Murata, M.; Nishimura, M.; Murai, N.; Haruta, M.; Homma, S.; Itoh, Y. A Transgenic Apple Callus Showing Reduced Polyphenol Oxidase Activity and Lower Browning Potential. Biosci. Biotechnol. Biochem. 2001, 65, 383-388. [CrossRef] [PubMed]

42. Richard-Forget, F.C.; Gauillard, F.A. Oxidation of Chlorogenic Acid, Catechins, and 4-Methylcatechol in Model Solutions by Combinations of Pear (Pyrus communis Cv. Williams) Polyphenol Oxidase and Peroxidase: A Possible Involvement of Peroxidase in Enzymatic Browning. J. Agric. Food Chem. 1997, 45, 2472-2476. [CrossRef]

43. Son, S.M.; Moon, K.D.; Lee, C.Y. Kinetic Study of Oxalic Acid Inhibition on Enzymatic Browning. J. Agric. Food Chem. 2000, 48, 2071-2074. [CrossRef] [PubMed]

44. Yoruk, R.; Marshall, M.R. A Survey on the Potential Mode of Inhibition for Oxalic Acid on Polyphenol Oxidase. J. Food Sci. 2003, 68, 2479-2485. [CrossRef]

45. Prenen, J.A.; Boer, P.; Dorhout Mees, E.J. Absorption kinetics of oxalate from oxalate-rich food in man. Am. J. Clin. Nutr. 1984, 40, 1007-1010. [CrossRef] [PubMed]

46. Altunkaya, A.; Gokmen, V. Effect of various inhibitors on enzymatic browning, antioxidant activity and total phenol content of fresh lettuce (Lactuca sativa). Food Chem. 2008, 107, 1173-1179. [CrossRef]

47. Ioniţă, E.; Stănciuc, N.; Aprodu, I.; Râpeanu, G.; Bahrim, G. pH-induced structural changes of tyrosinase from Agaricus bisporus using fluorescence and in silico methods. J. Sci. Food Agric. 2014, 94, 2338-2344. [CrossRef] [PubMed] 